\title{
EARTHWORM DIVERSITY AND HABITAT PREFERENCES IN ARID REGIONS OF RAJASTHAN
}

\author{
G. Tripathi ${ }^{1}$ and P. Bhardwaj ${ }^{2}$ \\ ${ }^{1}$ Department of Zoology, J.N.V. University, Jodhpur, Rajasthan 342001, India \\ 2 Corresponding author: H. No. 93, Shiv Nagar, Peer Baba Road, Baltana (Zirakhpur), Patiala, Punjab, India \\ 2 Email: drpbhardwaj@yahoo.co.nz
}

\begin{abstract}
Earthworms were surveyed in different habitats of Jodhpur District, Rajasthan, India. A total of nine earthworm species belonging to four different families, viz., Glossoscolecidae, Megascolecidae, Ocnerodrilidae and Octochaetidae were identified, of which six are first records for Jodhpur. The earthworm species differed in their eco-morphological characteristics and in relative abundance in each of the habitats sampled. Metaphire posthuma and Lampito mauritii were present in all the observed pedoecosystems. Ocnerodrilus occidentalis was found in all systems except garden soil, whereas Dichogaster boluai inhabited cultivated, non-cultivated and sewage soil. Pontoscolex corethururs, Amynthas morrisi and Ramiella bishambari were recorded from only sewage, garden and cultivated fields, respectively. The occurrence of most of the species in sewage soil as compared to other pedoecosystems may be related to high organic carbon and much higher nitrogen of the sewage system. This showed a remarkable species-habitat relationship. The relative density, frequency and species diversity index of some abundantly found earthworm species inhabiting particular habitat were also calculated. The entire observations clearly indicate the richness of earthworm biodiversity in the arid region of Rajasthan.
\end{abstract}

\section{KEYWORDS}

Arid, earthworm, habitat preference, Rajasthan

Earthworms play a prominent role in regulating soil-processes. They have been recognized as the most important soil ecosystem engineers (Lavelle et al., 1997; Santra \& Bhowmik, 2001). About 3,600 species of earthworms have been identified from the globe (Reynolds, 1994). India has a wide latitudinal range (between $8^{0} 4^{\prime}-37^{\circ} 6 \mathrm{~N}$ ) and complex topography, which are responsible for a varied climate that ranges from temperate to arctic in the Himalaya to tropical in the peninsular region. It has been divided into 15 broad agro-climatic zones or 21 agroeco regions for the implementation of agricultural planning and policies. However, the division of the country into 15 agro-climatic regions is considered adequate for evaluating its regional earthworm diversity (Julka, 2001). The destruction of native vegetation throughout the tropics has reached a critical level and there are no prospects of improving the situation. The changes in land use pattern are directly affecting the composition and population structure of earthworm species in different agro-climatic regions (Blanchart \& Julka, 1997; Behera et al., 1999; Bhadauria et al., 2000).

Though the area of India is only $2 \%$ of the world's total landmass, it harbours about $11.1 \%$ of the global earthworm diversity. Totally, 402 species and subspecies of earthworms belonging to 67 genera and 10 families have been identified from the country. The earthworm biodiversity in this region is predominantly represented by native species (357spp.), which constitute $88.8 \%$ of total earthworm diversity of India. Though the majority of the Indian forms have specific preference for natural habitats, a few exotic and ubiquitous Indian species have successfully colonized different agro-ecosystems. Julka (2001) has divided five earthworm diversity zones in India, viz., mega diversity, high diversity, medium diversity, low diversity and poor diversity zones. Some exotic peregrine forms (45 spp.) have also been introduced to the area, presumably by man and other agencies, in soil around roots of exotic plants (Gates, 1972; Julka, 1988). These exotic peregrine species mostly occur in disturbed habitats created by deforestation and intensive cultivation. Successful colonization of almost all agro-climatic zones in India by the exotic species is mainly due to their inherent ability to withstand disturbance and interference (Julka, 1988). Some widely distributed native peregrine species are also able to tolerate disturbed conditions. Native peregrine (local peregrine) species have now acquired a widespread distribution in different agro-ecosystems and some of these species are also beeing carried to other countries.

In subtropical and tropical regions there is wider variation in species rather than species richness (Kale \& Seenappa, 1997). Singh (1997) reported the occurrence of seven to 11 species from cultivated, non-cultivated, grassland, garden and sewage soils. The relative abundance and biomass of earthworms appears to decrease with decrease in soil moisture, soil acidity and palatability of food sources. The western dry region of India comprises of very poor earthworm diversity mainly due to highly degraded soils. But the agro-ecological conditions in this region are changing fast with irrigation and plantation facilities. No studies on the earthworm distribution of Jodhpur are available, except for three species (Julka, 1996). An attempt was made in the present study to investigate the distribution of earthworms in the semi arid region of Rajasthan. The study includes information concerning diversity, relative abundance and species-habitat relationship of earthworms in drier regions of Rajasthan.

\section{Materials And Methods \\ Study area}

An extensive survey was done during 1998-2000 in Jodhpur District, Rajasthan, India. This district with its six Tehsils is situated at the entrance of the Great Indian Thar Desert where normal rainfall ranges from $25-40 \mathrm{~cm}$. The archaean Aravalli Range in Rajasthan borders the Thar Desert in the east and Pakistan in the northwest. The Thar Desert $\left(26^{\circ} 45^{\prime} \mathrm{N} \& 7^{\circ} 03^{\prime} \mathrm{E}\right)$ is 
characterized by high atmospheric temperature, strong wind regime with wind speeds up to $30 \mathrm{~km} / \mathrm{h}$ leading to a high evaporating demand $(1,500-2,200 \mathrm{~mm} / \mathrm{year})$. This region is under the influence of the south-west monsoon (June-September) and during winter (December-March) by the Siberian anticyclone. The main rainy season is during July and August when almost $80 \%$ of the annual rains occur. All six tehsils (Jodhpur, Osian, Bilara, Bhopalgarh, Shergarh \& Phalodi) of Jodhpur District were covered in this investigation.

\section{Sampling}

Earthworms were collected by digging the soil up to a depth of $20 \mathrm{~cm}$ and hand sorting as described by Julka (1988). Soil lumps were broken and the soil was silted between fingers to sort out the worms. Earthworms were identified to the species level with the help of monographs of Stephenson (1923), Gates (1972) and Julka (1988). The identification of all the collected species were confirmed by Dr. Julka. The worms were sorted specieswise and preserved in 5\% formalin in the laboratory. Body colour and pigmentation of worms were recorded.

\section{Qualitative composition and habitat relationship}

The relative abundance of different earthworm species was studied in various habitats in the study sites. Sampling was done randomly from cultivated (wheat, bajra, mustard, cereals, citrus, onion, garlic fields, etc.), non-cultivated (grazing fallow \& waste lands), gardens (rose, palm tree, bougainvillea, Euphorbia, etc.), grassland (short grasses of various types) and sewage (kitchen, household, village sewage and civil drainage) sites. Samples were collected from one square metre marked area. The number of each earthworm species recorded per square metre area was categorized as abundant $(>20)$, moderate $(10-20)$ and poor $(<10)$. The ecological categories of earthworm species were also recorded. The physiochemical properties of soils from each sampling site were also analyzed in order to establish the possible species-habitat relationship. The parameters recorded include temperature, $\mathrm{pH}$, moisture and nutrients of soil. From these sites, certain cultivated, noncultivated, garden, grassland and sewage areas were selected to observe the seasonal changes in species of earthworm populations. The seasonal variations were recorded by marking five areas of one square meter in each field. Each selected field was monitored twice every month. The collected worms were sorted into aclitellate and clitellate for counting. Relative density, biomass, frequency, species diversity index (Shannon \& Weiner, 1963), index of dominance (Simpson, 1949), index of species richness (Margalef, 1968) and index of evenness (Pielou, 1966) were calculated.

\section{Soil analysis}

Soil samples were taken from each site for analysis. Soil $\mathrm{pH}$ $(1: 5 \mathrm{w} / \mathrm{v})$ was determined by using $\mathrm{pH}$ meter (Systronics System 362 ). Temperature at $10 \mathrm{~cm}$ depth was measured by soil thermometer and soil moisture content was estimated gravimetrically on a wet weight basis by oven drying at $105^{\circ} \mathrm{C}$. Organic carbon, total nitrogen, available phosphorus and exchangeable potassium were analyzed by Walkley and Black method (1934), Macro-Kjeldahl as described by Anderson and Ingram (1993), Olsen (1954) and ammonium acetate-extractable method described by Simard (1993), respectively.

\section{Results}

Diversity, qualitative composition and ecological categories Nine species of earthworms were recorded from Jodhpur District of Rajasthan (Table 1) comprising Pontoscolex corethrurus Müller, Amynthas morrisi (Beddard), Metaphire posthuma (Vaillant), Lampito mauritii Kinberg, Perionyx sansibaricus Michaelsen, Ocnerodrilus occidentalis Eisen, Dichogaster bolaui (Michaelsen), Ramiella bishambari (Stephenson) and Octochaetona paliensis (Stephenson). Lampito mauritii was abundant in cultivated and sewage soils, $P$. corethrurus and $P$. sansibaricus were abundantly present only in sewage. Likewise, A. morrisi was abundantly found only in garden soil. Octochaetona paliensis was recorded only from non-cultivated soils in moderate numbers. Metaphire posthuma was recorded from all pedoecosystems with its abundance in gardens. Dichogaster bolaui was abundant in sewage soil. Table 2 shows eco-morphological characteristics of earthworm species depending upon their feeding habits and body pigmentation. The occurrences of different species of earthworms were studied in relation to the physicochemical properties of their soil habitats (Table 3).

\section{Table 1. Diversity of earthworm species in different tehsils of Jodhpur District}

\begin{tabular}{|c|c|c|c|c|c|c|}
\hline Earthworm species & Jodhpur Tehsil & Osian Tehsil & Bilara Tehsil & Bhopalgarh & Tehsil Shergarh Tehsil & Phalodi Tehsil \\
\hline \multicolumn{7}{|l|}{ Glossoscolicidae } \\
\hline $\begin{array}{l}\text { Pontoscolex corethrurus } \\
\text { Megascolicidae }\end{array}$ & + & - & - & - & - & - \\
\hline Amynthas morrisi & + & - & - & - & - & - \\
\hline Metaphire posthuma & + & + & - & + & + & + \\
\hline Lampito mauritii & + & - & - & - & + & + \\
\hline $\begin{array}{l}\text { Perionyx sansibaricus } \\
\text { Ocnerodrilidae }\end{array}$ & + & - & - & - & - & - \\
\hline $\begin{array}{l}\text { Ocnerodrilus occidentalis } \\
\text { Octochaetidae }\end{array}$ & + & + & + & - & - & - \\
\hline Dichogaster bolaui & + & - & - & - & + & - \\
\hline Ramiella bishambari & + & - & - & + & - & - \\
\hline Ochtochaetona paliensis & + & - & - & - & - & - \\
\hline Total species & 9 & 2 & 1 & 2 & 3 & 2 \\
\hline
\end{tabular}

+ Present; - Absent 
Table 2. Eco-morphological characteristics with ecological categories of earthworm species of Jodhpur District of Rajasthan

\begin{tabular}{|c|c|c|c|c|c|c|}
\hline Species & Pigment & Length(mm) & Diameter(mm) & No. of segments & Fresh mass (g) & Ecologic category \\
\hline P. corethrurus & Unpigmented & $135-155$ & $4.0-4.9$ & $129-165$ & 1.08 & Endogeic \\
\hline A. morrisi & Reddish brown & $72-140$ & $3.9-4.9$ & $114-140$ & 1.13 & Epi-anecic \\
\hline M. posthuma & Brown & $68-135$ & $4.0-5.0$ & $98-129$ & 1.59 & Endo-anecic \\
\hline L. mauritii & Unpigmented & $75-150$ & $3.4-5.0$ & $83-166$ & 1.2 & Anecic \\
\hline P. sansibaricus & Dark purple & $85-115$ & $2.0-3.5$ & $94-135$ & 0.39 & Epigeic \\
\hline O. occidentalis & Unpigmented & $18-45$ & $0.9-1.6$ & $69-84$ & 0.038 & Endogeic \\
\hline R. bishambari & Light brown & $32-45$ & $0.8-1.3$ & $38-49$ & 0.013 & Endogeic \\
\hline D. bolaui & Unpigmented & $26-48$ & $1.5-3.0$ & $70-96$ & 0.05 & Epigeic \\
\hline O. paliensis & Unpigmented & $39-97$ & $2.0-4.0$ & $41-116$ & 0.42 & Endogeic \\
\hline
\end{tabular}

\section{Species diversity index}

Annual species diversity index $\left(\mathrm{H}^{\prime}\right)$ of earthworms in five pedoecosystems of Jodhpur were also studied. Species diversity index in grassland was zero which indicated the dominance by a single species $M$. posthuma. Two species, $D$. bolaui and $O$. paliensis were found in wasteland with Prosophis julifera, Zizyphus nummalaria, Acacia nilotica, etc., with an annual species diversity index of 0.67 . They showed shared dominance in this habitat. Maximum numbers of three species were recorded from each of the habitats like garden, cultivated land and sewage. This revealed higher annual species diversity index of 1.04 comprising of $M$. posthuma, A. morrisi and, $L$. mauritii in garden, 1.05 with D. bolaui, L. mauritii and, $M$. posthuma in cultivated land and, 1.06 in sewage with D. bolaui, P. sansibaricus and L. mauritii.

In grassland $M$. posthuma constituted $100 \%$ of the earthworm density, where value of dominance was one (Table 4). Index of dominance in non-cultivated land was 0.52 showing shared dominance of $D$. bolaui and $O$. paliensis. Whereas, index of dominance in garden, cultivated land and sewage was 0.36 which indicated shared dominance of three species in each of these habitats. The data on relative density (RD) and relative biomass (RB) showed that $M$. posthuma predominated in garden followed by $A$. morrisi and L. mauritii (Table 4). Dichogaster bolaui with a relative density of $44.2 \%$ was the most dominant species in cultivated land. Lampito mauritii and M. posthuma contributed $33.3 \%$ and $22.5 \%$ of density in this habitat, respectively. In sewage D. bolaui with relative density of $45.1 \%$ was predominant over $P$. sansibaricus (RD 32.6\%) and $L$. mauritii (RD 22.3\%). However, on the basis of worm biomass L. mauritii, P. sansibaricus and D. bolaui contributed $63.5 \%$, $31.4 \%$ and $5.1 \%$ in sewage, respectively.

\section{Discussion}

Present survey indicates the presence of nine species of earthworm species belonging to four different families of Oligochaeta (Glossoscolecidae, Megascolecidae, Ocnerodrilidae and Octochaetidae) in different parts of Jodhpur District. Earlier, only two families of earthworms were reported from Jodhpur (Julka, 1996). The earthworm diversity in Jodhpur District consists of exotic peregrines and native peregrines. There are no endemic earthworms in Rajasthan (Julka, 2001). The exotic are represented by A. morrisi, M. posthuma, D. bolaui, $O$. occidentalis and $P$. corethrurus. Presumably, the worldwide distribution of these exotic species is due to their transportation in soil around roots of exotic plants through the agency of man (Gates, 1972; Julka, 1988, 1993). Native Indian earthworms here are represented by $P$. sansibaricus, L. mauritii, $O$. paliensis and R. bishambari. The poor diversity in Jodhpur may be attributed to climatic conditions and soil texture in the area. Since Jodhpur is the gate of the Great Indian Thar Desert, its climate is very hot and dry. Texture of soil in this arid region is primarily sandy. Earthworms are generally absent or rare in soils with coarse texture probably due to the susceptibility to drought of such soils (Lee, 1985). Both exotic and native peregrine species found in Jodhpur have inherent ability to adapt to various types of soils (Lee, 1985; Julka, 1988). Exotic species like $A$. morrisi and $M$. posthuma and native peregrine species like $L$. mauritii that are widely distributed in Jodhpur area appear to be better adapted to withstand drought conditions, as they have enteronephric meronephric excretory system, i.e., excrete their urine into the gut, for conservation of water in their bodies (Lee, 1985).

Out of nine species of earthworms, six species, viz., A. morrisi, $P$. sansibaricus, $P$. corethrurus, D. bolaui, $O$. paliensis and $O$. occidentalis were recorded for the first time from Jodhpur District of Rajasthan. Among these, P. corethrurus, $P$. sansibaricus and $O$. paliensis were recorded for the first time from the pedoecosystems of Rajasthan. The most common earthworm species in almost all the observed habitats of Jodhpur were $M$. posthuma and L. mauritii. However R. bishambari occurred poorly in the region. The presence of a species in a particular habitat and its absence from other habitats shows the species-specific distribution of earthworms in different pedoecosystems. Similar conclusions have been observed from the species compositions of earthworms in different grassland, cultivated and forest soils (Satchell, 1983; Julka \& Senapati, 1986; Singh, 1997).

During the survey only L. mauritii was purely anecic species found in Jodhpur. This showed that the soil layers of more than $30 \mathrm{~cm}$ deep were not suitable for propagation of earthworms. The earthworm fauna of Jodhpur District may be epigeic, endogeic, epi-anecic, endo-anecic or anecic in nature.

The distribution of earthworms was mainly dependent on the physicochemical characteristics of the soil. Each habitat of this region mainly comprise of coarse loomy soil. Soil moisture, 
Table 3. Inhabitance of earthworms in relation to physicochemical characteristics of soils from different pedoecosystems

\begin{tabular}{|c|c|c|c|c|c|c|c|c|c|}
\hline Pedoecosystem & Species & $\begin{array}{l}\text { Temp. } \\
\left({ }^{\circ} \mathrm{C}\right)\end{array}$ & $\begin{array}{l}\text { Moisture } \\
(\%)\end{array}$ & $\mathrm{pH}$ & OC & $\mathrm{OM}$ & $\mathrm{TN}(\%)$ & $\mathrm{C} / \mathrm{N}$ ratio & Remarks \\
\hline Cultivated & $\begin{array}{l}\text { M. posthuma, } \\
\text { L. mauritii, } \\
\text { D. bolaui, } \\
\text { O. occidentalis, } \\
\text { R. bishambari }\end{array}$ & $19.6-33.7$ & $5.55-27.70$ & $7.0-8.0$ & $0.23-0.43$ & $0.39-0.75$ & $0.09-0.13$ & $2.56-3.31$ & $\begin{array}{l}\text { Samples were collected from } \\
\text { wheat, Bajara, mustard, } \\
\text { cereals, citrus, onion and } \\
\text { garlic fields }\end{array}$ \\
\hline Non-cultivated & $\begin{array}{l}\text { M. posthuma, } \\
\text { L. mauritii, } \\
\text { D. bolaui, } \\
\text { O. paliensis, } \\
\text { O. occidentalis }\end{array}$ & $21.5-34.0$ & $5.35-23.5$ & $7.0-7.6$ & $0.19-0.48$ & $0.32-0.82$ & $0.07-0.10$ & $2.71-4.80$ & $\begin{array}{l}\text { Samples were collected from } \\
\text { fallow lands and road sites }\end{array}$ \\
\hline Garden & $\begin{array}{l}\text { M. posthuma, } \\
\text { A. morrisi, } \\
\text { L. mauritii }\end{array}$ & $20.2-29.8$ & $6.02-28.43$ & $7.2-8.0$ & $0.43-0.81$ & $0.74-1.39$ & $0.10-0.14$ & $4.30-5.79$ & $\begin{array}{l}\text { Samples were collected from } \\
\text { rose, palm tree, tulsi, kaner } \\
\text { bouginvellia, euphorbia, etc. }\end{array}$ \\
\hline Grassland & $\begin{array}{l}\text { M. posthuma, } \\
\text { L. mauritii, } \\
\text { A. morrisi, } \\
\text { O. occidentalis }\end{array}$ & $20.8-33.2$ & $9.08-25.60$ & $7.5-8.0$ & $1.2-1.36$ & $2.75-3.20$ & $0.10-0.11$ & $12.0-12.36$ & $\begin{array}{l}\text { Samples were collected } \\
\text { from short grass lands }\end{array}$ \\
\hline Sewage & $\begin{array}{l}\text { M. posthuma, } \\
\text { L. mauritii, } \\
\text { P. sansibaricus, } \\
\text { O. occidentalis, } \\
\text { P. corethrurus, } \\
\text { D. bolaui }\end{array}$ & $20.3-30.0$ & $13.80-36.7$ & $7.0-8.0$ & $0.30-0.77$ & $0.52-1.33$ & $0.04-0.08$ & $7.50-9.60$ & $\begin{array}{l}\text { Samples were collected from } \\
\text { kitchen, household sewage, } \\
\text { civil drainage, near running } \\
\text { water }\end{array}$ \\
\hline
\end{tabular}

OC - Organic carbon; OM - organic matter; TN - total nitrogen; C/N - carbon/nitrogen

organic carbon and nitrogen was found to be significantly correlated with the distribution of the worms. This is in accordance with various studies done in different parts of India (Ismail \& Murthy, 1985; Ganihar, 1996). Soil pH in this region varied from slightly neutral to alkaline ( 7 to 8) (Table 3). Edwards and Lofty (1977) suggest that earthworm species generally have narrow range in $\mathrm{pH}$, very few being restricted to highly acidic soils $(\mathrm{pH}<4)$. Most of them prefer neutral soils, but some can tolerate acidic or alkaline soils. The $\mathrm{pH}$ values recorded in the present study are within the range for the distribution of earthworms. Ramiella bishambari inhabited cultivated soils while $O$. paliensis was found in non-cultivated soil, reflecting a clear cut species-habitat relationship. The occurrence of $R$. bishambari in cultivated soil might be related to higher nitrogen content. The earthworm species in garden and grassland were almost same except $O$. occidentalis which was only present in grassland having high carbon. The occurrence of most of the species in sewage soil as compared to other pedoecosystems may be related to high organic carbon and higher nitrogen in the sewage system. It shows that earthworms prefer to live in soil ecosystems rich in organic matter and nitrogen. The present observations are more or less in agreement to the findings of other workers (Lavelle, 1974; Edwards \& Lofty, 1977; Appelhof, 1981; Lee, 1985; Hallat et al., 1992). Various ecological parameters play a vital role in regulating the distribution of earthworms (Ismail et al., 1990). Many workers have also studied the habitat preference of various earthworm species (Singh, 1997; Bennour \& Nair, 1997; Scullion \& Malik, 2000).

Stable ecosystems have high species diversity as compared to unstable environments (May, 1979). Earthworm diversity is much more in natural systems than in interfered habitats (Lee, 1985). During the present investigations, grassland was found to be highly unstable dominated by a single species. Maximum index of species richness (d) with a value of 0.30 in cultivated land at Jodhpur more or less corresponds to the maximum (0.33) in an upland paddy field in Orissa as reported by Pani (1986). Index of species richness however was zero in grassland. Maximum index of species evenness $(\mathrm{e}=0.16)$ was estimated in cultivated land and a value of zero was recorded in grassland at Jodhpur. The lowest index of species dominance (e) with a value of 0.36 was calculated for human interfered habitats like garden, cultivated land and sewage during present investigations. Senapati and Dash (1981) also recorded lower index of species dominance for a highly distributed upland grazed pasture. However, higher values of 1.0 for grassland at Jodhpur corresponded to that of upland grazed pasture receiving kitchen waste as reported by Sahu (1988).

\section{REFERENCES}

Appelhof, M. (1981). Current progress in earthworms research. Biocycle 22: 36-38.

Behera, B.G., S. Dash, and N.C. Senapati (1999). Earthworm bioindicators of forest land use pattern. Indian Forester 124: 272-281. Bennour, S.A. and G.A. Nair (1997). Density and biomass and vertical distribution of Aporrectodea caliginosa (Savigny, 1826) (Oligochaeta, Lumbricidea) in Benghazi, Libya. Biology of Fertile Soil 24: 102-105. Bhadauria, T., P.S. Ramakrishna and K.N. Srivastava (2000). Diversity and distribution of endemic and exotic earthworms in natural and regeneration ecosystems in the central Himalaya, India. Soil Biology and Biochemistry 32: 2045-2054.

Blanchart, E. and J.M. Julka (1997). Influence of forest disturbance on earthworm (Oligochaeta) communities in the Western Ghats (South India). Soil Biology and Biochemistry 29: 303-306.

Edwards, C.A. and J.R. Lofty (1977). Biology of Earthworms. Chapman and Hall, New York, 333pp.

Ganihar, S.R. (1996). Earthworm distribution with special reference to physicochemical parameters. Proceedings of Indian National Science Academy 62: 11-18.

Gates, G.E. (1972). Burmese earthworms. An introduction to the systematics and biology of megadrile oligochaetes with special reference 
Table 4. Relative density (RD\%), relative biomass (RB\%) and relative frequency (RF\%) of earthworm species at five habitats during 1998-2000 in Jodhpur District

\begin{tabular}{|c|c|c|c|c|c|c|c|c|c|c|c|c|c|c|c|}
\hline \multirow[t]{2}{*}{ Earthworm species } & \multicolumn{3}{|c|}{ Cultivated field } & \multicolumn{3}{|c|}{ Non-cultivated field } & \multicolumn{3}{|c|}{ Garden } & \multicolumn{3}{|c|}{ Grassland } & \multicolumn{3}{|c|}{ Sewage } \\
\hline & RD & RB & RF & RD & RB & RF & RD & RB & RF & RD & RB & RF & RD & RB & $\mathbf{R F}$ \\
\hline Amynthus morrisi & - & - & - & - & - & - & 32.3 & 27.0 & 83 & - & - & - & - & - & - \\
\hline Metaphire posthuma & 22.5 & 31.8 & 83 & - & - & - & 45.5 & 53.4 & 100 & 100 & 100 & 83 & - & - & - \\
\hline Lampito mauritii & 33.3 & 65.9 & 92 & - & - & - & 22.2 & 19.6 & 100 & - & - & - & 22.3 & 63.5 & 100 \\
\hline Perionyx sansibaricus & - & - & - & - & - & - & - & - & - & - & - & - & 32.6 & 31.4 & 100 \\
\hline Dichogaster bolaui & 42.2 & 2.4 & 92 & - & 60.4 & 14.0 & 83 & - & - & - & - & - & 45.1 & 5.1 & 100 \\
\hline Octochaetona paliensis & - & - & - & - & 39.6 & 86.0 & 67 & - & - & - & - & - & - & - & - \\
\hline
\end{tabular}

to southeast Asia. Transactions of the American Philosophical Society 62: $1-326$.

Ismail, S.A. and V.A. Murthy (1991). Distribution of earthworms in Madras. Proceedings of Indian National Science Academy 94: 557566.

Ismail, S.A., C. Ramakrishnan and M.M. Anzar (1990). Density and diversity in relation to the distribution of earthworms in Madras. Proceedings of Indian Academic Sciences (Animal Science) 99: 73-78. Julka, J.M. (1988). The Fauna of India and the Adjeacent Countries. Megadrile: Oligochaeta (Earthworms). Haplotaxida: Lumbricina: Megascolecoidea: Octochaetidae. Zoological Survey of India, Calcutta, xiv +400 pp.

Julka, J.M. (1993). Earthworm resources of India and their utilization in vermiculutre, pp. 51-55. In: Earthworm Resources and Vermiculture. Zoological Survey of India, Solan.

Julka, J.M. (1996). Annelid diversity in the Thar Desert, pp.71-76. In: Ghosh, A.K., Q.H. Bagri and I. Prakash (Eds.). Faunal Diversity in the Thar Desert: Gaps in Research. Scientific Publishers, Jodhpur.

Julka, J.M. (2001). Distribution of earthworms in different agroclimatic regions of India. Workshop on Tropical Soil Biology and fertility programme. School of Environmental Sciences, J.N.U., New Delhi (in press).

Julka, J.M. and B.K. Senapati (1986). Earthworms (Oligochaeta: Annelida) of Orissa, India. Records in Zoological Survey of India, Occasional Paper 92: 1-44.

Kale, R.D.and S.N. Seenappa (1997). Earthworm in agriculture. Training Course on Organic Farming. UAS, Bangalore, pp.1-6.

Lavelle, P. Bignell, D. Lepage, M. Walter, V. Roger, P. Ineson, O.W. Heal and S. Dhillion (1997). Soil function in a changing world: The role of invertebrate ecosystem engineers. Journal of European Soil and Ecology 33: 159-193.

Lee, K.E. (1985). Earthworms. Their Ecology and Relationships with Soils and Land Use. Academic Press, London, 411pp.

Margalef, R. (1968). Perspective in Ecological Theory. University of Chicago Press, Chicago, 112pp.

May, R.M. (1979). The structure and dynamics of ecological communities, pp.385-407. In: Anderson, R.M., Turner, B.D., Taylor, L.R. (Eds.) Population Dynamics $20^{\text {th }}$ Symposium of British Ecological Society, Blackwell, Oxford.

Olsen, S.R., C.V. Cole, F.S. Watanable and L.A. Dean (1954). Estimation of Available phosphorus in Soils by Extraction with Sodium bicarbonate. Circular of U.S. Department of Agriculture, 939pp.

Pani, S.C. (1986). Aspects of ecological studies on tropical earthworms in irrigated agricultural system of Orissa, India. Ph.D. Thesis, Sambalpur University, Orissa, India (Unpublished).

Pielou, E.C. (1966). The measurement of diversity in different types of biological collections. Journal of Theoretical Biology 13: 145-163. Reynolds, J.W. (1994). The distribution of the earthworms (Oligochaeta) of Indiana: A case for the post-theory for magadrile migration in North America. Megadrilogica 5: 13- 32.

Sahu, S.K. (1988). The ecological implication of interspecific variations in some tropical earthworms from pasture ecosystem on Orissa India Ph.D. Thesis, Sambalpur University, Orissa, India (Unpublished).

Santra, S.K. and K.L. Bhowmik, (2001). Vermiculture and development of agriculture, pp.43-45. In: Yojana (March).

Satchell, J.E. (1983). Earthworms Ecology - from Darwin to
Vermiculture. Chapman and Hall, London, 495pp.

Scullion, J. and A. Malik (2000). Earthworm activity affecting organic matter, aggregation and microbial, activity in soils restored after opencast mining for coal. Soil Biology and Biochemistry 32: 119126.

Senapati, B.K. and M.C. Dash (1981). Effect of grazing on the elements of production in the vegetation and oligochaete components of a tropical pasture land. Review on Ecology and Biology of Soils 18: 487-505.

Shannon, C.E. and W. Weiner (1963). The mathematical theory of communication. University of Illinois Press, Urbana, $117 \mathrm{pp}$.

Simard, R.R. (1993). Ammonium acetate extractable elements, pp.3943. In: Martin, R. and S. Carter (Eds.). Soil Sampling and Method of Analysis. Lewis Publishers, Florida.

Simpson, E.H. (1949). Measurement of diversity. Nature, London 163: 688 .

Singh, J. (1997). Habitat preferences of selected Indian earthworm species and their efficiency in reduction of organic materials. Soil Biology and Biochemistry 29: 585-588.

Stephenson, J. (1923). Oligochaeta. The Fauna of British India, including Ceylon and Burma. Taylor and Francis, London, xxiv+518pp. Walkley, A. and I.A. Black (1934). An examination of the Degtjareff method for determining soil organic matter and prepared modifications of the chromic acid titration method. Soil Sciences 34: 29-38.

\section{ACKNOWLEDGEMENT}

The Department of Biotechnology (DBT), Govt. of India, New Delhi is gratefully acknowledged for providing financial support to complete the work. Thanks to Dr. J.M. Julka, Emeritus Scientist, Zoological Survey of India, Solan (H.P.) for helping in identification of the species.

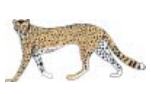

